\title{
SUBSIDIARY PROJECT PLAN REQUIREMENTS FOR PUBLIC CONSTRUCTION PROJECTS IN TRINIDAD AND TOBAGO
}

\author{
Amrita Baal ${ }^{1}$ and Derek Outridge ${ }^{2}$ \\ ${ }^{1,2}$ Faculty of Engineering, The University of the West Indies, Trinidad \\ ${ }^{1}$ Email: amritabaal@hotmail.com \\ ${ }^{2}$ Email: derek.outridge@sta.uwi.edu
}

\begin{abstract}
In 2010, the Commission of Enquiry into the Construction Sector of Trinidad and Tobago found that Public Construction Projects (PCPs) in Trinidad and Tobago suffered significant schedule overrun due to a lack of project planning, specifically at the design stage, which costed the country several millions of TT dollars. The Enquiry's revelation prompted this study, to assess the significance of the Subsidiary Project Plans (SPPs) at the design stage of PCPs. The assessment of the impact of SPPs on project schedule, based on its level of production, was executed via statistical analyses, in the Statistical Package for the Social Sciences, utilizing 62 questionnaire responses. The relationship between the level of production of each SPP and project schedule was investigated via a correlation analysis revealing that SPPs are significantly neglected at the design stage of PCPs in Trinidad and Tobago which in turn adversely affected project schedule. Further statistical analysis on each SPP revealed that only $22 \%$ of the total number of SPPs that can be produced were done, at $51 \%$ adequacy.

This significant finding in the study highlighted its impact on and importance to project schedule and by extension, project cost. A minimum set of SPPs to be produced, at the design stage of Public Construction Projects in Trinidad and Tobago, is recommended for standardisation as it is expected to substantially reduce the probability of project delays and cost overruns. The findings will educate construction project professionals and stakeholders on the SPPs' importance and its contribution to project success and sustainable construction standards.
\end{abstract}

Keywords: Construction industry, Project design, Project planning, Project schedule, Subsidiary project plans, Design management, Sustainable construction.

\section{https://doi.org/10.47412/JRND8949}

\section{Introduction}

\section{Delays in Construction Projects in Trinidad and Tobago}

In 2010 the Commission of Enquiry investigated into the Construction Sector in Trinidad and Tobago (The Uff Report). The Uff Report found that numerous PCPs executed by the Government experienced innumerable delays amounting to as much as four times the original contract period, with others ranging from one to fifteen months delays, averaging at thirty-three percent of the original contract period. Of the main contributors to these delays, incomplete designs, design errors, design changes, variations and the "fast-tracking" approach that some projects were executed under, were found to be among the most common [14]. This indicates that most schedule 
delays experienced on PCPs are a result of insufficient or lack of project planning, specifically, subsidiary project plans. Inevitably, these resulted, and will continue to result in high cost overruns, costing the country and by extension, the public's purse, considerable millions of TT dollars.

Resulting from these findings, the Uff Report recommended that the Cabinet Oversight Committee create a range of Standard Procedure Documents (SPDs) for the construction industry of Trinidad and Tobago to ensure that;

a) designs are completed prior to project tendering

b) variations be approved only for situations which were unforeseeable at the design stage

c) there are disincentives to discourage the acceptance of incomplete designs

Since these recommendations were made in 2010, to date, no official attempt to its development and implementation has been made. As a result, the construction sector of Trinidad and Tobago is still exposed to these severe sources of delays. Thus, immediate action in addressing these recommendations is crucial.

\section{Subsidiary Project Plans}

The final product of the Design Management Stage of a construction project is the Project Management Plan which is composed of smaller, more detailed project plans known as the subsidiary project plans (SPPs), prepared during the planning of the project. The SPPs programs and directs the project by defining the methods to achieve project goals, project deliverables, detailing all project execution plans and activities, risk responses and monitoring and controlling techniques [2]. These plans take into consideration all foreseeable factors and influences on the project activities, allowing for more effective management, reduced uncertainties and reduced cost/budget overruns [10]. Such plans include, but are not limited to, the scope management plan, cost management plan, time management plan, quality management plan and logistics plan and the health and safety plan. Carrying such significant weight towards the successful completion of projects, the SPPs are classified as a fundamental module to the Project Management Plan, without which the success of projects will be highly at risk.

\section{Construction Projects Design Stage Planning}

Each year companies worldwide overlook the benefits of developing and maintaining a formal pre-construction planning process, i.e. design stage planning (DSP) prior to contract tendering and award, ultimately leading to cost and schedule overruns [9]. Inevitably, the issue arises when the lack of this planning results in incomplete designs, designs errors, scope changes and lack of SPPs [7] [3] [9]. Hence, ensuring that the DSP process in projects is carried out extensively is essential [16]. Adequate DSP can significantly increase the success of projects by construction management standards with greater client satisfaction, more consistent on-time and within-budget completion and more effective teamwork. This is made possible by setting goals to prepare the structure for project execution and control, by defining project objectives, work requirements, schedules, methods, strategies, tactics, targets, resources required, and deadlines to achieve project objectives [5] [4] [9] [16].

Whilst there exist numerous studies on project planning and its impact on project success and/or failure, the majority is focused on the construction stage of projects, after the contract has been awarded, with few focusing DSP [15]. This brings about the need for investigations into the effects of the DSP, to determine its significance to project success. This necessity originates from the fact 
that the design management stage sets the tone for the entire project, having substantial influence on the overall project success whereby any decision and information, or lack thereof, would have a ripple effect on the project going forward.

At the design stage a conceptual design is completed where the project strategy and its strategic alignment with the project program is envisaged. Once the project team reaches a consensus on the conceptual design, it is then progressed to a standard design stage. At this stage the project requirements, issues, constraints, limitations, possibilities, risks, feasibility and specifications are deduced, ultimately enclosing a detailed design stage. Also all detailed project plans are prepared with requirements, estimates of duration, cost and resource allocations, and appropriate monitoring measures, forming the baseline for the project [6]. Without DSP, project scope, deliverables, limitations, procedures, techniques and specifications will be indefinite, making it merely impossible to effectively execute each project task to achieve the project goal. This makes the project more susceptible to mismanagement as there is no benchmark to monitor or from which to direct project activities, leading to the delays and cost overruns identified by previous research conducted globally.

Despite this high importance and significant influence on project performance and success, the design stage, and its processes, are readily overlooked and underestimated, such that sufficient time is not spent on its completion, resulting in its expected outputs (the SPPs) not being delivered as required at the necessary standard and/or quality [12].

Runwanpura et al (2006) aimed at identifying the critical and non-critical project activities in order to produce a list of generic critical activities that impact final cost of Engineering, Procurement and Construction Projects (EPC) in Canada. The study revealed for the project design stage, the most critical activities were finalization of scope, detailed schedule, detailed design, detailed cost estimate and preparation of work packages. However, whilst these findings relate to the project design stage, it does not encompass all aspects, specifically, an assessment of its SPPs, investigating its significance towards the impact on final costs on the EPCs.

Evaluating the levels of use of project documents and its influence on final project outcome, Idoro (2012) sought to assist stakeholders in comparing the project documents prepared with its influence on project performance via a comparison between procurement method (traditional contracts and design-build contracts), project planning and project outcome. Idoro (2012) discovered that project performance is dependent on the levels of project plans prepared and used for both methods of procurement investigated. The study proposed that increased levels of project plans prepared and utilisation at the various phases of projects will enhance project outcome in terms of its cost, time and quality. However, this study lacked a thorough examination of all SPPs and their possible impact on project performance.

Emerging from the studies conducted on project planning and DSP in construction projects, there is a clear indication of a gap in the knowledge area, thorough investigations into all possible SPPs at the design management stage of construction projects and their direct impact on project success. Research in this realm is imperative in order to clearly understand how each SPPs has its individual impact on project schedule, cost and quality. Through understanding of its impact, its significance can be determined and thus its minimum standard can be set, in order to limit the negative impacts that can incur in future projects. 
This study investigates the significance of all possible subsidiary project plans at DSP of public construction projects in T\&T. The levels of SPPs production presents the adverse impacts its absence has on project schedule and its direct relation to the paucity of project success as it pertains to PCPs in Trinidad and Tobago. The study proposes a Standard Procedure Document (SPD) for PCPs in Trinidad and Tobago in the form of a minimum set of SPPs required at the design stage of PCPs. These SPPs are expected to allow for better control and monitoring of key aspects of Trinidad and Tobago's PCPs from the design stage onward. Through the implementation of this SPD, a reduction of project delays is expected, along with reductions in cost overruns, potentially saving the economy of Trinidad and Tobago billions of TT dollars, further allowing for higher probabilities of achieving project success from all points of the "iron triangle"; quality, cost and time.

\section{Hypothesis}

A hypothesis was postulated for this study:

"Subsidiary project plans are not significantly produced at the design stage of PCPs in Trinidad and Tobago."

Testing this hypothesis is expected to confirm whether or not SPPs are significantly produced at the DSP of Public Construction Projects in T\&T, which can then further be used to confirm the impact such has on project schedule. The result is expected to arouse project stakeholders to reevaluate the quality and effectiveness of their planning efforts at the design management stage, identify the shortcomings and improve the overall production of SPPs at the design stage to PCPs.

\section{Variables:}

Independent Variable: Each Subsidiary Project Plan

Dependent Variable: Project Schedule

\section{Methodology}

\section{Data Collection Procedures}

Adopted from the study "Comparing levels of use of project plans and performance of traditional contract and design-build construction projects in Nigeria." by Idoro (2012), this study encompasses a mixed method research analysis, combining quantitative and qualitative research methods. A questionnaire survey was employed to gather the quantitative data which served as the study's primary data while a desktop study was employed for the qualitative data collection, serving as the secondary dataset.

\section{Questionnaire Survey}

The questionnaire survey was designed to gather information that would determine:

i. If SPPs are significantly prepared at the design stage of PCPs in T\&T.

ii. Whether or not the SPPs produced affect T\&T's PCPs' schedules.

iii. The significance of each SPP to T\&T's construction industry.

\section{Desktop Study}

A desktop study was conducted in order to:

i) Gather and analyse existing information relating to the topic of investigation. 
ii) Obtain a further guide on executing the study based on the methods employed previously by researchers and their achievements.

\section{Reliability Testing}

In assessing the reliability of the research design, Cronbach's coefficient alpha test in SPSS was applied to the questionnaire survey, which gave the average correlation among all the items that make up the scale (Pallant, 2013).

Table 1: Case Processing Statistics Statistics

\begin{tabular}{|c|c|c|}
\hline & $\mathrm{N}$ & $\%$ \\
\hline Cases Valid & 62 & 100.0 \\
\hline Excluded $^{\mathrm{a}}$ & 0 & .0 \\
\hline Total & 62 & 100.0 \\
\hline
\end{tabular}

\section{Table 2: Reliability}

\begin{tabular}{|c|c|}
\hline $\begin{array}{c}\text { Cronbach's } \\
\text { Alpha }\end{array}$ & $\begin{array}{c}\text { No of } \\
\text { items }\end{array}$ \\
\hline 0.946 & 23 \\
\hline
\end{tabular}

${ }^{\text {a }}$ Listwise deletion based on all variables in the procedure

Validity Testing

In testing the validity of the research design, a pilot test was conducted with experts in the field. Based on their knowledge and expertise, a critic of the research design was completed and returned to the researcher with comments and suggestions. The survey was amended and then distributed to the selected sample.

\section{Sampling Design}

The population selected for this research were construction professionals actively practicing in the industry in T\&T. The simple random sampling technique was employed to select the sample for the questionnaire survey, allowing everyone within the population an equal chance in being selected, capturing all perspectives of the industry in an unbiased manner. This allowed for a wider range of different knowledge, experiences and skill sets to be captured, giving the data more depth and credibility.

In determining the sample size for this research, Kish (1965) formula was applied, at a confidence level of $95 \%$ [1]

Kish (1965) formula:

For a sample size from a finite population, n;

Where: $\mathrm{N}=$ total population $=855$

$$
\mathrm{n}=\frac{n^{1}}{\left[1+\left(\frac{n^{1}}{N}\right)\right]}
$$

$\mathrm{n}^{1}=$ a sample size from an infinite population $=\mathrm{s}^{2} / \mathrm{v}^{2}$

$\mathrm{s}^{2}=$ variance of the population $=(0.5)^{2}$

A variance of $50 \%$ was selected for this research as to allow and account for maximum variance possible

$\mathrm{v}^{2}=$ standard error $=(0.06)^{2}$ 
A sample size of 64 was obtained. Idoro (2012) targeted a sample size of 84 persons for the Nigerian construction industry. Thus, using Idoro's sample size as a guide and Kish's formula as the determining factor, it was found that a minimum of 64 responses from the questionnaire survey would result in a reliable dataset.

\section{Data Analysis Procedures}

In analysing the data of this study, the Standard Multiple Regression Analysis (SMRA) in IBM's Statistical Packages for Social Sciences (SPSS), was utilised. Employed to explore the predictability of impact of each SPP on project schedule, the SMRA investigated the influence of the independent variables on the dependent variable, further used to predict a best fit model in relation to the dependent variable (Pallant 2013). Investigated in this analysis was the influence and predictability of the SPPs (the independent variables) on project schedule (the dependent variable).

\section{Hypothesis Testing}

For this study a null hypothesis $\left(\mathrm{H}_{0}\right)$ was stated;

"Subsidiary project plans are not significantly produced at the design stage of PCPs in Trinidad and Tobago."

In testing this hypothesis, an alternative hypothesis $\left(\mathrm{H}_{1}\right)$ was developed;

"Subsidiary project plans are significantly produced at the design stage of PCPs in Trinidad and Tobago."

In SPSS, the One-Way ANOVA was used to provide statistical evidence inferring whether or not there were significant differences in the means of the variables as obtained from the questionnaire survey. If the p-value (sig. value) obtained from the test was $>0.05$, the null hypothesis would be accepted, rejecting the alternative and vice versa if the p-value was $<0.05$.

It should be noted that in SPSS there are numerous assumptions made for the ANOVA test. These are:

1. The expected values of errors are zero

2. The variances of all errors are equal to each other

3. The errors are independent

4. The variables are normally distributed

\section{Results and Discussion}

For initial investigations of this study, the main issues and effects of SPPs in PCPs in T\&T were determined utilising data obtained from the literature review and the questionnaire survey. 
Table 3: Summary of the main issues with SPPs in T\&T and the effects experienced.

\begin{tabular}{|l|l||l|l|}
\hline \multicolumn{2}{|c||}{ Main Issues with SPPs in T\&T's PCPs } & \multicolumn{2}{c|}{ Main Effects Experienced } \\
\hline $\begin{array}{l}\text { Questionnaire } \\
\text { Survey }\end{array}$ & $\begin{array}{l}\text { Uff and Thornhill } \\
(2010)\end{array}$ & $\begin{array}{l}\text { Questionnaire } \\
\text { Survey }\end{array}$ & $\begin{array}{l}\text { Uff and } \\
\text { Thornhill } \\
(2010)\end{array}$ \\
\hline $\begin{array}{l}\text { Lack of types of } \\
\text { SPPs produced }\end{array}$ & $\begin{array}{l}\text { Increased Cost } \\
\text { and Time }\end{array}$ & \\
\hline $\begin{array}{l}\text { Lack of } \\
\text { completeness in a } \\
\text { timely manner }\end{array}$ & $\begin{array}{l}\text { Lack of timely design } \\
\text { submission }\end{array}$ & $\begin{array}{l}\text { Increased Cost } \\
\text { and Time }\end{array}$ & $\begin{array}{l}\text { Increased Cost } \\
\text { and Time }\end{array}$ \\
\hline $\begin{array}{l}\text { Lack of quality of } \\
\text { the SPPs } \\
\text { produced }\end{array}$ & $\begin{array}{l}\text { Incomplete/Inadequate } \\
\text { project design }\end{array}$ & $\begin{array}{l}\text { Increased Cost } \\
\text { and Time }\end{array}$ & $\begin{array}{l}\text { Increased Cost } \\
\text { and Time }\end{array}$ \\
\hline
\end{tabular}

Immediately, the first observation made from Table 3 is the severe issues PCPs face with its SPPs and the evident effects as was previously determined in the Uff Report. The results of this study shown in Table 3 corroborate and validate the identified severe issues. These results indicate that since 2010, the severe issues faced in the construction sector of T\&T persists, as no official attempts were made to reduce and/or eliminate them. This inevitably facilitates continuous exposure to the same threats, indicating the critical need to address the lack of SPPs at the design stage of PCPs in T\&T, thus producing a solution for standardisation as recommended by the Uff Report.

An assessment carried out in this study was to determine the perceived importance of each SPP to the professionals operating in the construction industry of T\&T to determine the level of production of the same SPPs in PCPs of T\&T. The level of production of each SPP and its relative importance to project schedule is presented in Table 4. This gave rise to the understanding and knowledge to the lack of implementation within the construction sector.

Table 4: SPPs level of production in order of their relative importance.

\begin{tabular}{|l|c|c|c|}
\hline \multirow{2}{*}{$\begin{array}{c}\text { Subsidiary Project } \\
\text { Plan }\end{array}$} & \multicolumn{2}{|c|}{$\begin{array}{c}\text { Commonly } \\
\text { Produced }\end{array}$} & $\begin{array}{c}\text { Relative } \\
\text { Importance } \\
\text { (Likert Scale) }\end{array}$ \\
\cline { 2 - 3 } & Yes (\%) & No (\%) & 5 \\
\hline Bill of Quantities & 52 & 48 & 5 \\
\hline Structural Drawings & 50 & 50 & 5 \\
\hline $\begin{array}{l}\text { Risk Management } \\
\text { Plan }\end{array}$ & 23 & 77 & 5 \\
\hline Civil /Site Design & 52 & 48 & 4 \\
\hline $\begin{array}{l}\text { Time Management } \\
\text { Plan }\end{array}$ & 36 & 64 & 4 \\
\hline $\begin{array}{l}\text { Cost Management } \\
\text { Plan }\end{array}$ & 39 & 61 & 4 \\
\hline $\begin{array}{l}\text { Mechanical } \\
\text { Drawings }\end{array}$ & 48 & 52 & 4 \\
\hline Cash Flow & 40 & 60 & 4 \\
\hline Electrical Drawings & 53 & 47 & 4 \\
\hline
\end{tabular}


Faculty of Engineering, The UWI, St. Augustine | June $1^{\text {st }}-5^{\text {th }}, 2020$

\begin{tabular}{|l|c|c|c|}
\hline $\begin{array}{l}\text { Health and Safety } \\
\text { Plan }\end{array}$ & 37 & 63 & 4 \\
\hline $\begin{array}{l}\text { Architectural } \\
\text { Drawings }\end{array}$ & 50 & 50 & 4 \\
\hline $\begin{array}{l}\text { Scope Management } \\
\text { Plan }\end{array}$ & 26 & 74 & 4 \\
\hline $\begin{array}{l}\text { Quality } \\
\text { Management Plan }\end{array}$ & 19 & 81 & 4 \\
\hline $\begin{array}{l}\text { Environmental } \\
\text { Impact Assessment } \\
\text { Report }\end{array}$ & 26 & 74 & 4 \\
\hline $\begin{array}{l}\text { Procurement } \\
\text { Management Plan }\end{array}$ & 16 & 84 & 4 \\
\hline $\begin{array}{l}\text { Communication } \\
\text { Management Plan }\end{array}$ & 19 & 81 & 4 \\
\hline
\end{tabular}

Table 4 continued.

\begin{tabular}{|l|c|c|c|}
\hline \multirow{2}{*}{$\begin{array}{c}\text { Subsidiary Project } \\
\text { Plan }\end{array}$} & \multicolumn{2}{|c|}{$\begin{array}{c}\text { Commonly } \\
\text { Produced }\end{array}$} & \multirow{2}{*}{$\begin{array}{c}\text { Relative } \\
\text { Importance } \\
\text { (Likert Scale) }\end{array}$} \\
\cline { 2 - 3 } & Yes (\%) & No (\%) & 4 \\
\hline $\begin{array}{l}\text { Stakeholder } \\
\text { Management Plan }\end{array}$ & 24 & 76 & 4 \\
\hline Logistics Plan & 16 & 84 & 4 \\
\hline $\begin{array}{l}\text { Human Resource } \\
\text { Management Plan }\end{array}$ & 13 & 87 & 4 \\
\hline $\begin{array}{l}\text { Constructability } \\
\text { Report }\end{array}$ & 10 & 90 & 4 \\
\hline $\begin{array}{l}\text { Value Engineering } \\
\text { Report }\end{array}$ & 10 & 90 & 4 \\
\hline Sustainability Plan & 3 & 97 & 3 \\
\hline Resource Histogram & 8 & 92 & 3 \\
\hline
\end{tabular}

The data in Table 4 confirms the statements made in the Uff Report that SPPs are not being readily produced prior to project execution for T\&T's PCPs (inadequate/incomplete project design). Only 5 SPPs were commonly produced at the design stage of construction projects in T\&T as evidence by the $51 \%$ rate. This practice is unacceptable when taking into consideration the impact that SPPs have on project schedule. Highlighted in red are the SPPs that are not commonly produced in T\&T which accounts for $78 \%$ of those shown in Table 4, even though they are of high relative importance.

The following section of the study ascertains the direct level of impact each SPP has on project schedule delays. In achieving this, the SMRA explored the degree to which each of the SPPs directly impacted project schedule and the predictability of the effect occurring. The results are presented in Table 5. 
Table 5 Results obtained from SPSS Multiple Regression Analysis.

\begin{tabular}{|c|c|c|c|c|c|c|}
\hline \multicolumn{7}{|c|}{ Coefficients } \\
\hline \multirow{2}{*}{ Rank } & \multirow{2}{*}{ Model } & \multicolumn{2}{|c|}{$\begin{array}{c}\text { Unstandardised } \\
\text { Coefficients }\end{array}$} & \multirow{2}{*}{$\begin{array}{c}\begin{array}{c}\text { Standardised } \\
\text { Coefficients }\end{array} \\
\text { Beta }(\beta)\end{array}$} & \multirow{2}{*}{$\mathrm{t}$} & \multirow{2}{*}{$\begin{array}{l}\text { Sig. } \\
(\mathrm{p}- \\
\text { value })\end{array}$} \\
\hline & & $\begin{array}{c}\text { Beta } \\
(\beta)\end{array}$ & $\begin{array}{l}\text { Std. } \\
\text { Error }\end{array}$ & & & \\
\hline & (Constant) & 1.178 & .076 & & 15.558 & .000 \\
\hline 1 & Structural Drawings & .189 & .035 & 1.123 & 5.338 & .000 \\
\hline 2 & Architectural Drawings & -.135 & .023 & .932 & -5.949 & .000 \\
\hline 3 & Bill of Quantities & -.059 & .022 & .594 & -2.698 & .010 \\
\hline 4 & Electrical Drawings & .060 & .028 & .380 & 2.184 & .035 \\
\hline 5 & Cash Flow & -.054 & .023 & .361 & -2.342 & .025 \\
\hline 6 & $\begin{array}{l}\text { Procurement } \\
\text { Management Plan }\end{array}$ & .029 & .018 & .218 & 1.649 & .051 \\
\hline 7 & Mechanical Drawings & -.031 & .029 & .204 & -1.067 & .002 \\
\hline 8 & Risk Management Plan & -.027 & .019 & .165 & -1.438 & .000 \\
\hline 9 & $\begin{array}{l}\text { Quality Management } \\
\text { Plan }\end{array}$ & .023 & .024 & .156 & .928 & .010 \\
\hline 10 & Civil & -.019 & .035 & .113 & -.531 & .033 \\
\hline 11 & $\begin{array}{l}\text { Stakeholder } \\
\text { Management Plan }\end{array}$ & -.013 & .016 & .109 & -.797 & .041 \\
\hline 12 & Constructability Report & -.011 & .014 & .096 & -.811 & .011 \\
\hline 13 & Logistics Plan & -.010 & .018 & .090 & -.598 & .067 \\
\hline
\end{tabular}


Table 5 continued.

\begin{tabular}{|c|c|c|c|c|c|c|}
\hline \multicolumn{7}{|c|}{ Coefficients } \\
\hline \multirow{2}{*}{ Rank } & \multirow{2}{*}{ Model } & \multicolumn{2}{|c|}{$\begin{array}{l}\text { Unstandardised } \\
\text { Coefficients }\end{array}$} & \multirow{2}{*}{$\begin{array}{l}\text { Standardised } \\
\text { Coefficients } \\
\text { Beta }(\beta)\end{array}$} & \multirow{2}{*}{$\mathrm{t}$} & \multirow{2}{*}{$\begin{array}{c}\text { Sig. } \\
(\mathrm{p}- \\
\text { value })\end{array}$} \\
\hline & & $\begin{array}{l}\text { Beta } \\
(\beta)\end{array}$ & $\begin{array}{l}\text { Std. } \\
\text { Error }\end{array}$ & & & \\
\hline 14 & Health and Safety Plan & .012 & .017 & .086 & .746 & .033 \\
\hline 15 & $\begin{array}{l}\text { Value Engineering } \\
\text { Report }\end{array}$ & -.011 & .019 & .085 & -.567 & .005 \\
\hline 16 & $\begin{array}{l}\text { Human Resource } \\
\text { Management Plan }\end{array}$ & .008 & .018 & .074 & .472 & .041 \\
\hline 17 & Cost Management Plan & .010 & .018 & .067 & .531 & .036 \\
\hline 18 & Scope Management Plan & -.007 & .017 & .051 & -.433 & .002 \\
\hline 19 & $\begin{array}{l}\text { Environmental Impact } \\
\text { Assessment Report }\end{array}$ & .005 & .021 & .034 & .247 & .020 \\
\hline 20 & Time Management Plan & -.002 & .021 & .013 & -.094 & .000 \\
\hline 21 & Resource Histogram & .001 & .012 & .010 & .091 & .071 \\
\hline 22 & Sustainability Plan & .001 & .015 & .007 & .047 & .004 \\
\hline 23 & $\begin{array}{l}\text { Communication } \\
\text { Management Plan }\end{array}$ & .001 & .019 & .005 & .028 & .006 \\
\hline
\end{tabular}

This information presents that key values are the standardised coefficient Beta and its relative pvalue. The standardised coefficient values allow for relative comparison between each of the independent variable (the SPPs) by converting its values to the same scale [11]. The beta coefficient indicates the strength of the influence of each independent variable (the SPPs) on the dependent variable (project schedule delays) whereby the larger the beta coefficient (regardless of the leading sign character) the stronger the influence of the independent variable is to the dependent variable [11]. Table 5 presents the results of the SMRA in a ranked format, from the most influential SPP to the least influential SPP based on its respective standardised $\beta$ coefficient.

The primary observation made was the significance of the data to the resulting best fit model (the p-value). Except for the Procurement Management Plan, the Logistics Plan and the Resource Histogram, all SPPs contribute significantly to the "best fit" model (sig. value < 0.05) [11].The best fit model is derived based on the different levels of influence each SPP has on project schedule as shown as the "Rank" in Table 5. The information resulting from the SMRA was regarded as essential as it allowed for the absolute assessment of the significance of each SPP to project schedule based on its influential capacity. 
Further to assessing the individual impact each SPP has on project schedule, the One-Way ANOVA test was employed to test the hypothesis of this study to determine whether or not SPPs are significantly produced at the design stage of PCPs in T\&T. The results of this test are presented in Table 6.

Table 6: Results of the One-Way ANOVA test on the hypothesis of the study.

\begin{tabular}{|c|c|c|c|c|c|}
\hline & Sum of Squares & df & Mean Square & F & Sig. \\
\hline Between Groups & .089 & 1 & .089 & .415 & .522 \\
\hline Within Groups & 12.600 & 59 & .214 & & \\
\hline Total & 12.689 & 60 & & & \\
\hline
\end{tabular}

The resulting p-value of $0.522(>0.05)$ indicates there is no significant difference between the means of the levels of production of SPPs in T\&T, the null hypothesis (Ho) of this study failed to be rejected, proving that SPPs are not significantly produced at the design stage of PCPs in T\&T.

With the discovery of the significance of SPPs to project schedule and that SPPs are not significantly produced at the design stage of PCPs in T\&T, an objective was set to develop an optimum set of SPPs to be produced at the design stage of PCPs in T\&T. Using the ranking obtained from the results of the SMRA the optimum set of SPPs to be produced was selected based on the most influential SPPs as the greater the influence, the greater the significance to project scheduled. These are presented in Table 7.

Table 7: Optimum set of SPPs to be produced at the design stage of PCPs in T\&T.

\begin{tabular}{|c|c|c|c|c|c|c|}
\hline \multirow{2}{*}{$\begin{array}{c}\operatorname{Ran} \\
\mathbf{k}\end{array}$} & \multirow{2}{*}{ Model } & \multicolumn{2}{|c|}{$\begin{array}{l}\text { Unstandardise } \\
\text { d Coefficients }\end{array}$} & \multirow{2}{*}{$\begin{array}{c}\begin{array}{c}\text { Standardise } \\
\text { d } \\
\text { Coefficients }\end{array} \\
\beta \\
\end{array}$} & \multirow[t]{2}{*}{$\mathbf{t}$} & \multirow[t]{2}{*}{ Sig. } \\
\hline & & $\boldsymbol{\beta}$ & \begin{tabular}{|l} 
Std. \\
Error
\end{tabular} & & & \\
\hline & (Constant) & 1.178 & .076 & & $\begin{array}{c}15.55 \\
8\end{array}$ & .000 \\
\hline 1 & Structural Drawings & .189 & .035 & 1.123 & 5.338 & .000 \\
\hline 2 & Architectural Drawings & -.135 & .023 & .932 & $\begin{array}{c}- \\
5.949\end{array}$ & .000 \\
\hline 3 & Bill of Quantities & -.059 & .022 & .394 & $\begin{array}{c}- \\
2.698\end{array}$ & .010 \\
\hline 4 & Electrical Drawings & .060 & .028 & .380 & 2.184 & .035 \\
\hline 5 & Cash Flow & -.054 & .023 & .361 & $2 . \overline{342}$ & .025 \\
\hline 6 & $\begin{array}{l}\text { Procurement } \\
\text { Management Plan }\end{array}$ & .029 & .018 & .218 & 1.649 & .108 \\
\hline 7 & Mechanical Drawings & -.031 & .029 & .204 & $\begin{array}{c}- \\
1.067\end{array}$ & .293 \\
\hline 8 & Risk Management Plan & -.027 & .019 & .165 & $\begin{array}{c}- \\
1.438\end{array}$ & .159 \\
\hline 9 & $\begin{array}{l}\text { Quality Management } \\
\text { Plan }\end{array}$ & .023 & .024 & .156 & .928 & .359 \\
\hline 10 & Civil/Site Design & -.019 & .035 & .113 & -.531 & .599 \\
\hline
\end{tabular}




\begin{tabular}{|c|l|c|c|c|c|c|}
\hline 11 & $\begin{array}{l}\text { Stakeholder } \\
\text { Management Plan }\end{array}$ & -.013 & .016 & .109 & -.797 & .431 \\
\hline 12 & Constructability Report & -.011 & .014 & .096 & -.811 & .423 \\
\hline 13 & Logistics Plan & -.010 & .018 & .090 & -.598 & .553 \\
\hline 14 & Health and Safety Plan & .012 & .017 & .086 & .746 & .460 \\
\hline & Value Engineering & -.011 & .019 & .085 & -.567 & .574 \\
15 & Report & & & & & \\
\hline
\end{tabular}

The most significant SPP to project schedule success are these presented in Table 7. Hence, PCPs in T\&T should produce, at a minimum, these $15 \mathrm{SPP}$ at the design stage. The adequate preparation of these fifteen SPPs, but not limited to, in T\&T's PCPs, it is expected that projects will experience less delays and cost overrun as found by previous researchers who conducted similar research in other construction sectors [3] [4] [5] [9] [13] [15].

\section{Conclusion}

The Uff Report provided severe issues impacting the success of PCPs in T\&T. Of these issues were the lack of timely design submission and incomplete/inadequate project design. Additionally, the Uff Report presented evidence of the adverse effects of these severe issues, an increase in project time and cost, amounting to as much as four times the original contract period and $30 \%$ of the original contract sum. In investigating the sources of these severe issues identified, it was determined to be the lack of SPPs developed at the design stage of projects. To date, no official attempts were made within the industry to rectify these severe issues. This study pursued the recommendation given in the Uff Report in developing Recommendations for Good Practice to ensure designs are complete before projects are offered for tender, variations be required only where matters arise that were unforeseeable at design stage and to discourage the use of provisional sums or the acceptance of incomplete designs. In doing so, this study aimed at determining the significance of design stage SPPs to project schedule success and developing a minimum set of SPPs to be produced at the design stage of PCPs to provide a Standard Procedure Document for the construction industry of T\&T.

The results of this study revealed that significant SPPs are not produced at the design stage of PCPs in T\&T, being one of the leading causes of the significant schedule overrun and the inevitable cost overruns experienced, costing the government of T\&T. In attempts to reduce these impacts and repercussions, a minimum set of SPPs to be produced at the design stage of PCPs in T\&T is proposed for standardisation. This minimum set of SPPs determined is expected to achieve reductions in project schedule delays and cost overruns. In turn, this will save the country, and the public's purse, millions of TT dollars, allow for increased project efficiency, enhance project management throughout the project and result in higher levels of project success and sustainability.

\section{Limitations}

The results of this study were limited to:

1. A limited number of previous studies conducted on determining the level of significance of each SPPs for comparison. 
2. The type and depth of analysis possible was limited to the type and appropriateness of data collected.

\section{Recommendations}

In further developing this study, the following actions are recommended:

1. Standardise the optimum set of fifteen SPPs presented in Table 5, making it a minimum requirement for all PCPs in T\&T prior to project tendering with a disciplinary committee charged with the responsibility of ensuring these standards are kept and maintained in all PCPs going forward through a review and approval process.

2. This study directly addressed only two of the eight critical factors at the design stage of PCPs in T\&T which significantly contribute to project delays as identified in the Uff Report. As a result, further research in investigating the remaining six factors, listed below, is required;
a. Inadequate/Inaccurate soil investigations
b. Lack of project data
c. Lack of design reviews information
d. Invalid project
e. Failure to carry out adequate site investigations f. Lack of supervision/management

3. This study could be further developed by considering the various procurement methods employed in PCPs in T\&T. This will thus bring about standardisations designed to specifically meet the requirements of the different procurement methods utilised in PCPs.

\section{References}

[1] S. A. Assaf \& S. Al-Hejji. 2006. Causes of Delay in Large Construction Projects. International Journal of Project Management 24, 349-357.

[2] E. Chung. 2014. PMP Certification Essentials - The Project Management Plan (PM Plan) Explained. Retrieved 02 15, 2018, from https://edward-designer.com/web/pmp-exam-essentialsproject-management-plan-pm-plan-explained/

[3] H. Doloi, A. Sawhney, K. Iyer, \& S. Rentala. 2011. Analysing Factors Affecting Delays in Indian Construction Projects. International Journal of Project Management, 479-489.

[4] D. Dvira, T. Razb \& A. J. Shenharc. 2003. An Empirical Analysis of The Relationship Between Project Planning and Project Success. International Journal of Project Management 21 (2003), 89-95.

[5] G. Idoro. 2012. Comparing Levels of Use of Project Plans and Performance of Traditional Contract and Design-Build Construction Projects in Nigeria. Journal of Engineering, Design and Technology Vol. 10 No. 1, 7-33.

[6] L. A. Ika. 2012. Project Management for Development in Africa: Why Projects are Failing and What Can Be Done About It. Project Management Journal, 27-41.

[7] V.R. Montequin, S.M. Cousillas, V. Alvarez, and J. Villanueva. 2016. Success Factors and Failure Causes in Projects: Analysis of Cluster Patterns Using Self-Organizing Maps. International Conference on Project Management, 100: 440-448. Procedia Computer Science. Oviedo, Spain. 
[8] N. Mani. 2011. Impact of Design Cost on Project Performance of Design Bid Build Projects. Las Vegas: Howard R. Hughes College of Engineering, University of Nevada.

[9] C. L. Menches. 2006. Effect of Pre-construction Planning on Electrical Project Performance. Madison: University of Wisconsin.

[10] J. Nicholas \& H. Steyn. 2008. Project Management for Business, Engineers, and Technology (3rd ed.). Burlington, MA: Butterworth-Heinemann Publishers.

[11] J. Pallant. 2013. SPSS Survival Manual. New York: The McGraw Hill Companies.

[12] E. L. Pierson, J. Horne, \& D. Stein. 2017. Two Case Studies on The Most Critical Construction Planning Factors That Promote High Project Performance. Minnesota: Capella University.

[13] J.Y. Ruwanpura, T.N. Ahmed, K. Kaba \& G.P. Mulvany. 2006. Project Planning and Scheduling and its Impact to Project Outcome: A study of EPC Projects in Canada. AACE International Transactions, 201-209.

[14] J. Uff \& D. Thornhill. 2010. Report of The Commission of Enquiry into the Construction Sector Trinidad and Tobago. Trinidad and Tobago: The Government of the Republic of Trinidad and Tobago.

[15] J.-B.Yang \& P.-R.Wei. 2010. Causes of Delay in the Planning and Design Phases for Construction Projects. Journal of Architectural Enineering .

[16] O. Zwikael. 2009. The Relative Importance of The PMBOK® Guide's Nine Knowledge Areas During Project Planning. Project Management Journal, 94-103. 